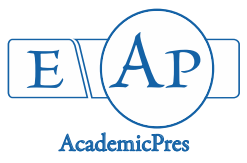

David M et al. (2020)

Notulae Scientia Biologicae 12(4):869-883

DOI: $10.15835 / 12410843$

Research Article

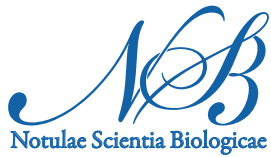

\title{
Pollen grain expression of osmotic adjustment as a screening method on drought tolerance in several wine and table grape genotypes (Vitis vinifera L.)
}

\author{
Monica DAVID a , Andrei TIȚA ${ }^{\text {b* }}$, Ionela D. TOMA, \\ Cristina-Magdalena CIOBOTEA, Mădălina F. BĂNUT, Ă
}
National Research and Development Institute for Biotechnology in Horticulture Ştefăneşti-Argeş, 37 Şoseaua București-Piteşti, Argeș,117715Ştefăneşti, Romania; davidmonica233@yahoo.com; tita_andrei10@yahoo.com ("corresponding author); ionela.toma93@yahoo.com; cioboteacristina76@yahoo.com;serban_madalina16@yahoo.com ${ }^{a, b}$ These authors contributed equally to the work

\begin{abstract}
Osmotic adjustment is one of the important mechanisms to adapt to drought and it is the only one which is activated under any level of water stress in the plant cells. Grapevine pollen grains response was tested to osmotic stress in fourteen genotypes, initiated by immersion in $55 \%$ or $65 \%$ polyethylene glycol solutions without and with addition of potassium chloride, to estimate the expressions of osmotic adjustment. The pollen grain test found differences both in the measurements of projected area cytoplasm and expressions of osmotic adjustment present in the cells. Italian Riesling increased pollen grains cytoplasm in PEG solutions with added $\mathrm{KCl}$ much more than other genotypes and had the high values for both expressions of induced and overall osmotic adjustment. The results obtained for expression of induced osmotic adjustment underlined the high $\mathrm{K}^{+}$accumulation capacity of 'Italian Riesling', 'Burgund mare' 86 Şt., 'Muscat d'Adda' 22 Şt., 'Muscat Ottonel' 16 Şt., 'Pinot gris' 14 Şt. and 'Argessis'. The lack of correlation between expressions of induced and intrinsic osmotic adjustment indicated that induced osmotic adjustment expressed by $\mathrm{K}^{+}$might use different mechanisms that are activated at the time of water stress with different levels of solute accumulation. Because the accumulation of $\mathrm{K}^{+}$in the cells is important in all developmental stages and, in grape yield and quality, pollen responses to induced osmotic adjustment expressed by $\mathrm{K}^{+}$could be used as a screening method, for establishing the level of drought sensitivity in the grape varieties under water stress.
\end{abstract}

Keywords: cytoplasm; grapevine clones; osmosis; plasmolysis; water deficit

Abbreviations: ABA-abscisic acid; $\mathrm{KCl}$-potassium chloride; $\mathrm{Mg}^{2+}$-magnesium ion; OA-osmotic adjustment; PEG $\left(\mathrm{K}^{+}\right)$-polyethylene glycol with addition of $\mathrm{KCl}$

\section{Introduction}

The frequency of extreme drought is predicted to increase, influencing negatively the yield and quality of grapes. Drought may lead to massive leaf shedding with a consequent source-sink imbalance and incomplete berry maturation due to insufficient available carbohydrates (Chaves et al., 2010). For understanding 
physiological and molecular bases of plant responses to mild and moderate water deficits, Blum (2009) has been recommended that the research must be conducted between vegetative and reproductive development, aiming to find the best solutions for improving crop water use and controlling fruit quality under drought conditions (Chaves et al., 2007, 2010).

Osmotic adjustment capacity, which allows maintaining the plant cell turgescence by accumulation of organic or inorganic osmolytes as response to water stress, is one of the important characteristics to adapt to water deficit (Morgan, 1983, 1999). Many crop plants, and also woody shrubs and trees, respond to drought conditions by intracellular net accumulation of solutes, as has been documented in sorghum (Jones and Turner, 1980), wheat (Morgan, 1980; Morgan et al., 1986; Kikuta and Richter, 1988), corn (Sobrado, 1990) and several trees species (Parker and Pallardy, 1985; Sobrado, 1986; Tschaplinski and Blanke, 1989; Rodrigues et al., 1993). As osmoticum adjustment is a cellular mechanism, it is expressed in all plant cells, including pollen grains and this offers a convenient way to characterize germplasm for this trait (Morgan, 1999; Moud and Yamagishi, 2005).

Patil and Ravikumar (2011) have been differentiated two responses of pollen projected area to osmotic stress, in their work on sorghum. The response induced by stress solutions (PEG) without addition of inorganic osmolyte was considered as expression of "intrinsic" osmotic adjustment, while the response to external supply of inorganic osmolyte to the stress solutions was described as expression of "induced" osmotic adjustment. Researches on wheat plants identified large differences among cultivars, given by these two types of pollen grain responses to osmotic stress (Morgan et al., 1986; Bănică et al., 2008; David, 2009; David, 2012). The K+, as an inorganic osmolyte, has an important role in pollen hydration and pollen tube growth under water stress in grapevine, being controlled by inward $\mathrm{K}^{+}$channel activity (Mouline et al., 2002; Zhao et al., 2013; Cuéllar et al., 2013; Rogiers et al., 2017).

Following the pollen grain test performed as a screening method on drought sensitivity in other crop plants, this paper presents the results obtained for estimation of induced and intrinsic OA expressions present in the cells, using quantitative measurements of projected pollen grain cytoplasm area, in a diverse grapevine set, aiming to characterize wine and table grape varieties for drought tolerance response.

\section{Materials and Methods}

\section{Plant material}

A set of fourteen grapevine genotypes were studied for their pollen grain expressed osmotic adjustment, using the test of pollen grain developed by Morgan (1999) on wheat plants.

The varieties were characterized by Glăman et al. (2018) as:

1. Drought tolerant varieties: 'Italian Riesling'; 'Victoria'; 'Argessis', 'Burgund mare' 86 Şt.; 'Fetească albă' 97 Şt.; 'Muscat d'Adda' 22 Ş..; 'Muscat Ottonel' 16 Şt.; 'Pinot gris' 14 Şt.; 'Pinot noir' 3 Şt.; 'Şarbă' 2 Şt.; 'Sauvignon petit' 111 Şt. and 'Chardonnay' 15 Şt.

2. Drought sensitive cultivar: 'Tămâioasă Românească'.

3. No information about drought sensitivity: 'Ştefăneşti'.

\section{Greenhouse conditions}

Grapevine genotypes (Vitis vinifera L.) of 10 years old were planted in pots $\left(20 \mathrm{dm}^{3}\right)$ containing a soil:peat:sand mixture (3:1:0.5). Inside the greenhouse, the maximum and means of temperature were $27^{\circ} \mathrm{C}$ and $18{ }^{\circ} \mathrm{C}$, respectively, at the time when flowers at anthesis were collected. The humidity was between $30 \%$ and $80 \%$, respectively. The grapevine plants received drip irrigation to induce moderate water stress. 


\section{Grapevine pollen test}

Grapevine pollen grains are similar with those of wheat plants (Oprea and Indreaş, 2000). Therefore, the procedure of wheat pollen test developed by Morgan (1999) was used on grapevine pollen grains. The pollen grains of matured anthers were soaked in polyethylene glycol (PEG 10,000) solutions of 55\% and 65\%, over microscope slides, with and without addition of $10 \mathrm{mM} \mathrm{KCl}$ for each concentration of PEG solutions. After a little agitation to release the pollen grains, the anther sections were removed and then, the solutions covered with a cover slip. The slides were incubated at $20^{\circ} \mathrm{C}$ for 1 day. Microscopic observations were made using a magnification of 20X. A stressing concentration of PEG induced shrinkage of the pollen grains cytoplasm, which assumed a more conical shape, often with concavities.

The following parameters were recorded (Patil and Ravikumar, 2011):

A-Initial cytoplasm area (Control) induced in PEG solution of $30 \%$.

B-The projected cytoplasm area of pollen grains, after 24 hours of osmotic stress induced by $55 \%$ and 65\% PEG solutions.

C-The projected cytoplasm area of pollen grains, after 24 hours of incubation in 55\% and 65\% PEG solutions with addition of $10 \mathrm{mM} \mathrm{KCl}$ to solutions.

Measurements of projected pollen grains cytoplasm were made using the Quickphoto2.3 tools designed by Olympus Imaging Software.

Estimation of osmotic adjustment expressions induced in grapevine pollen grains

Based on the theory proposed by Patil and Ravikumar (2011), estimation of osmotic adjustment expressions induced in grapevine pollen grains was determined using:

1. The ratios (B/A) of projected pollen cytoplasm area induced under stress (mean of both $55 \%$ and $65 \%$ PEG without $\mathrm{KCl}$ ) on the non-stressed initial cytoplasm area, as a measure of intrinsic $\mathrm{OA}$.

2. The ratios $(\mathrm{C} / \mathrm{B})$ of projected pollen cytoplasm area induced under stress with external osmolyte supply (mean of 55\% and 65\% PEG with addition of $\mathrm{KCl}$ ) on the projected pollen cytoplasm area induced under stress (mean of $55 \%$ and $65 \%$ PEG without $\mathrm{KCl}$ ), as a measure of induced OA.

3. The ratios (C/A) of projected pollen cytoplasm induced under stress with external osmolyte supply (mean of 55\% and 65\% PEG with addition of $\mathrm{KCl}$ ) on non-stressed initial cytoplasm area, as a measure of overall OA.

Ratio coefficients expressed in means obtained for estimation of osmotic adjustment response at different levels of osmotic stresses induced in the pollen grains which had values $\geq 1$, indicated in our screening the level of drought sensitivity in grapevine genotypes for each OA expression.

\section{Statistical analysis}

The statistical interpretation of the results was conducted using analysis of variance (Fischer-Snedecor test). Analysis of variance was performed in Excel for each treatment and trait in three repetitions given by measurements of projected pollen grain cytoplasm area made on the images focused in three central locations of the slide observed at magnification of 20X. The significance of results was compared through LSD test (Steel et al., 1997), corresponded to a significant limit of 5\%. The results of LSD test were expressed both in absolute and relative values. Analysis of the relationships among traits given by expressions of osmotic adjustment were examined through calculation of correlation coefficients $(\mathrm{R})$.

\section{Results}

Because when pollen grains are immersed in water or 15\% PEG, they decreased and increased in size and/or burst, the initial cytoplasm area was considered the area measured after 24 hours of immersion in a nonstressing solution of $30 \%$ PEG (Figure 1). 

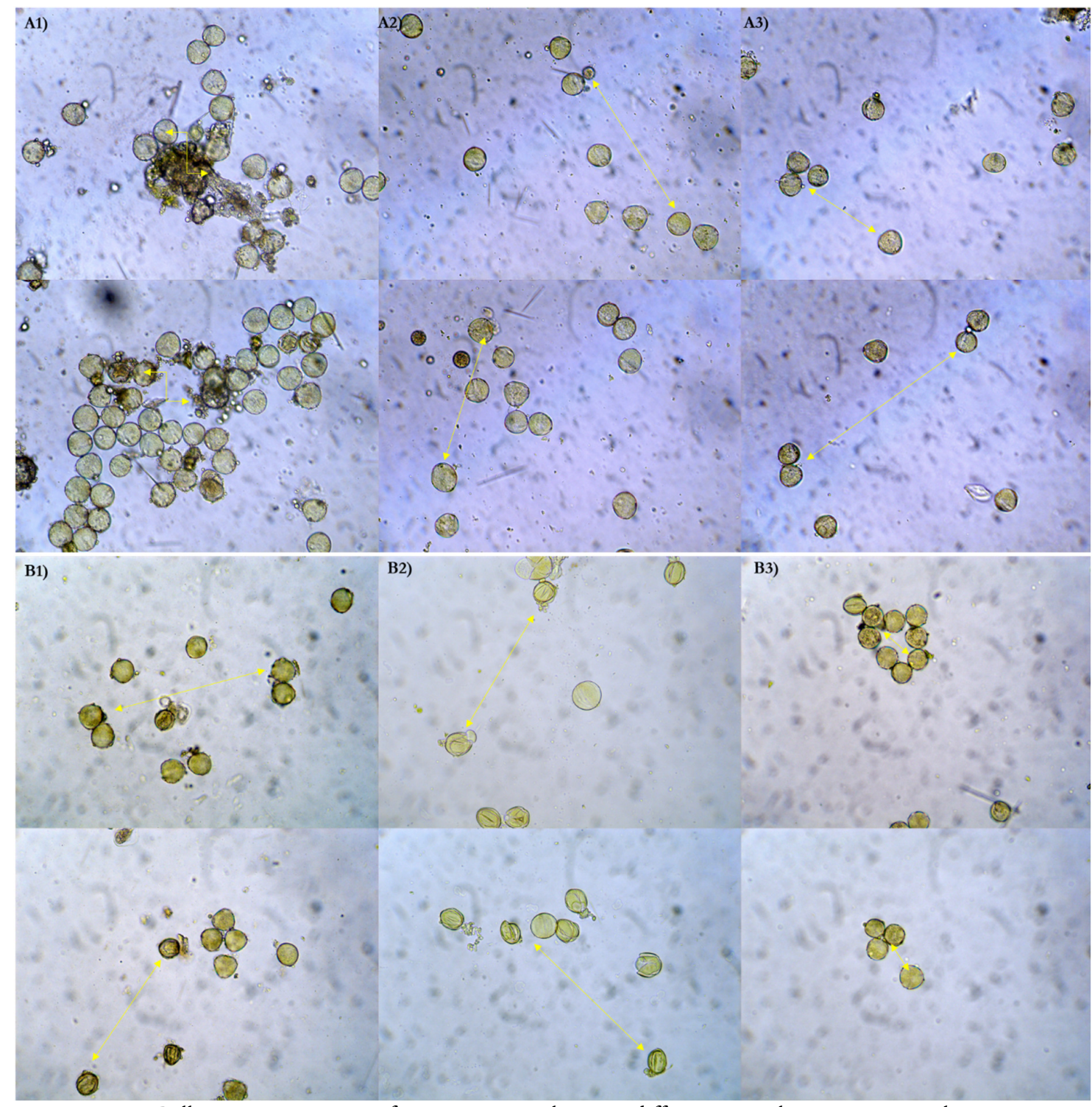

Figure 1. Pollen grain expressions of two grapevine cultivars in different control treatments given by image repetitions focused on Olympus microscope at magnification of $20 \mathrm{X}$

(A1.) 'Argessis' pollen grains exposed to distillate water, modulated by a decreasing, and increasing in cytoplasm area or by broken cells (arrows); (A2.) 'Argessis' pollen grains exposed to 15\% PEG: the same pollen grains expression as in images A1. (arrows); (A3.) 'Argessis' pollen grains exposed to 30\% PEG: homogeneous expression of pollen grains cytoplasm (arrows); (B1.) Pollen grains of 'Ş̧tefăneşti' exposed to distillate water, modulated by a decreasing, and increasing in cytoplasm area or by broken cells (arrows); (B2.) Pollen grains of 'Ştefăneşti' exposed to 15\% PEG modulated by broken cells (arrows); (B3.) Pollen grains of 'Ş̧tefăneşti' exposed to 30\% PEG: homogeneous expression of pollen grains cytoplasm (arrows).

Differences between genotypes regarding the projected area of pollen grains cytoplasm in non-stressing and stressing PEG solution

Large differences were found in the measurements expressed in means of the projected cytoplasm area of pollen grains, subjected to various levels of osmotic stress in PEG solutions, among the studied grapevine genotypes (Table 1).

The means of projected pollen cytoplasm area for all 14 grapevine genotypes expressed in $55 \%$ and $65 \%$ PEG solutions were smaller than the mean of pollen cytoplasm area expressed as control (30\% PEG) by $29.96 \%$ 
and $34.87 \%$, respectively. Adding $\mathrm{KCl}$ to the PEG solutions, the means of projected pollen cytoplasm area were smaller than the mean of control by $22.16 \%$ and $28.57 \%$, respectively (Table 2 ).

Grapevine genotypes had different responses to the applied osmotic stress treatments. Each pollen grain cell was measured on the slide. As in wheat pollen grain test, at the microscopic level, the lack of cell uniformity given by grape pollen grains conducted to large standard deviations calculated for each genotype (Table 2).

The pollen grain responses to different osmotic stresses were different among grapevine genotypes (Figure 2). Grapevine projected area of pollen cytoplasm decreased after immersion in PEG solutions by more than $21.3 \%$ in 'Şarbă' 2 Şt. or $46.8 \%$ in 'Tămâioasă Românească' (Figure $2\left(\mathrm{~A}^{*}\right.$.; $\mathrm{C}^{*}$.; $\mathrm{D}^{*}$.)) and greatly increased with $27.3 \%$ in 'Italian Riesling' or $23.5 \%$ in 'Victoria' (Figure $2\left(\mathrm{E}^{*}.\right)$ ), after addition of $\mathrm{KCl}$ in the PEG solutions. The projected area of pollen cytoplasm barely changed by less than $2.7 \%$ in 'Sauvignon petit' 111 Şt., $2.5 \%$ in 'Fetească albă' 97 Şt. or (-) 3.3\% in 'Chardonnay' 15 Şt. (Figure $2\left(E^{*}.\right)$ ).

Table 1. ANOVA of measurements expressed in means of projected area of pollen grains cytoplasm

\begin{tabular}{|c|c|c|c|c|}
\hline \multicolumn{5}{|c|}{ ANOVA of: } \\
\hline Projected pollen cytoplasm area in 55\% PEG & DF & MS & Fischer Factor & $\operatorname{Pr}(>\mathrm{F})$ \\
\hline Variables as varieties & 13 & $120,954.05$ & $32.64^{* *}$ & 2.09 \\
\hline $\begin{array}{l}\text { Estimation of general errors determined by all } \\
\text { experimental differences }\end{array}$ & 28 & $3,706.19$ & & \\
\hline Projected pollen cytoplasm area in $55 \%$ PEG $\left(\mathrm{K}^{+}\right)$ & DF & MS & Fischer Factor & $\operatorname{Pr}(>F)$ \\
\hline Variables as varieties & 13 & $164,412.97$ & $65.05^{* * *}$ & 2.09 \\
\hline $\begin{array}{l}\text { Estimation of general errors determined by all } \\
\text { experimental differences }\end{array}$ & 28 & $2,527.50$ & & \\
\hline Projected pollen cytoplasm area in $65 \%$ PEG & $\mathrm{DF}$ & MS & Fischer Factor & $\operatorname{Pr}(>F)$ \\
\hline Variables as varieties & 13 & $257,259.54$ & $65.21^{* * *}$ & 2.09 \\
\hline $\begin{array}{l}\text { Estimation of general errors determined by all } \\
\text { experimental differences }\end{array}$ & 28 & $3,945.06$ & & \\
\hline Projected pollen cytoplasm area in $65 \% \mathrm{PEG}\left(\mathrm{K}^{+}\right)$ & DF & MS & Fischer Factor & $\operatorname{Pr}(>F)$ \\
\hline Variables as varieties & 13 & $295,520.71$ & $41.01^{* *}$ & 2.09 \\
\hline $\begin{array}{l}\text { Estimation of general errors determined by all } \\
\text { experimental differences }\end{array}$ & 28 & $7,205.31$ & & \\
\hline
\end{tabular}

$\mathrm{F}$ values (bold) were significant for $\mathrm{P}<0.05$; where DF means degrees of freedom; MS means mean square; Fischer factor means practical F; $\operatorname{Pr}(>\mathrm{F})$ means theoretical F

Table 2. Means \pm standard deviations of projected pollen cytoplasm area $\left(\mu \mathrm{m}^{2}\right)$ expressed in control $(30 \%$ PEG) and stressing solutions without and with addition of $\mathrm{KCl}$; LSD values were corresponded to a significant limit of $5 \%$ and were expressed both, in absolute and relative values

\begin{tabular}{|c|c|c|c|c|c|}
\hline \multirow{2}{*}{ Genotype } & \multicolumn{3}{|c|}{ Means of projected pollen cytoplasm area $\left(\mu \mathrm{m}^{2} \pm\right.$ standard deviation) expressed after exposure to solutions of: } \\
\cline { 2 - 5 } & $30 \%$ PEG & $55 \%$ PEG & $65 \%$ PEG & \multicolumn{2}{c|}{$55 \%$ PEG $\left(\mathrm{K}^{+}\right)$} \\
\hline Chardonnay 15 Şt. & $1,039.87 \pm 633.1$ & $966.47 \pm 402.8$ & $946.17 \pm 213.6$ & $866.27 \pm 564.4$ & $996.07 \pm 200.7$ \\
\hline Şarbă 2 Şt. & $1,461.53 \pm 579.9$ & $1,341.10 \pm 252.1$ & $1,040.10 \pm 358.2$ & $1,196.20 \pm 247.3$ & $1,022.18 \pm 302.7$ \\
\hline Feteasca albă 97 Şt. & $1,365.73 \pm 408.2$ & $1,234.17 \pm 151.2$ & $1,131.57 \pm 205.4$ & $1,314.40 \pm 233.3$ & $1,118.87 \pm 232.9$ \\
\hline Pinot noir 3 Şt. & $1,242.63 \pm 504.1$ & $1,055.37 \pm 225.7$ & $789.33 \pm 172.4$ & $1,113.70 \pm 135.3$ & $825.27 \pm 136.3$ \\
\hline Italian Riesling & $970.73 \pm 346.9$ & $812.63 \pm 154.73$ & $765.43 \pm 160.5$ & $1,070.47 \pm 359.0$ & $1,101.20 \pm 216.7$ \\
\hline Muscat d'Adda 22 Şt. & $1,514.10 \pm 328.6$ & $1,101.23 \pm 236.4$ & $1,158.03 \pm 319.0$ & $1,379.30 \pm 212.6$ & $1,430.63 \pm 262.3$ \\
\hline Ştefăneşti & $1,538.07 \pm 316.8$ & $1,090.30 \pm 157.2$ & $1,221.23 \pm 225.9$ & $1,055.23 \pm 239.4$ & $1,083.20 \pm 306.7$ \\
\hline Argessis & $1,597.67 \pm 216.8$ & $1,107.13 \pm 304.2$ & $1,430.73 \pm 271.2$ & $1,259.77 \pm 304.4$ & $1,631.70 \pm 187.0$ \\
\hline Burgund mare 86 Şt. & $1,267.02 \pm 448.6$ & $865.60 \pm 349.9$ & $1,044.2 \pm 261.8$ & $1,520.87 \pm 288.8$ & $950.07 \pm 344.2$ \\
\hline Pinot gris 14 Şt. & $1,357.97 \pm 396.6$ & $891.3 \pm 262.17$ & $417.27 \pm 131.1$ & $1,066.93 \pm 136.6$ & $422.33 \pm 117.7$ \\
\hline Sauvignon petit 111 Şt. & $2,170.47 \pm 534.2$ & $1,370.93 \pm 398.3$ & $1,296.23 \pm 388.5$ & $1,354.97 \pm 282.8$ & $1,388.17 \pm 241.9$ \\
\hline Muscat Ottonel 16 Şt. & $1,595.73 \pm 284.5$ & $923.03 \pm 299.3$ & $519.95 \pm 169.1$ & $1,015.33 \pm 322.2$ & $743.03 \pm 220.1$ \\
\hline Tămâioasă Ro. & $1,262.33 \pm 457.7$ & $671.37 \pm 201.17$ & $703.53 \pm 188.8$ & $585.57 \pm 276.7$ & $724.20 \pm 156.3$ \\
\hline Victoria & $2,077.03 \pm 235.8$ & $899.10 \pm 320.97$ & $862.43 \pm 237.7$ & $1,127.07 \pm 253.1$ & $1,178.40 \pm 419.1$ \\
\hline Average & $1,461.49$ & $1,023.55$ & 951.87 & $1,137.57$ \\
\hline LSD 5\%-abs. values & 73.22 & 34.98 & 36.09 & $1,043.95$ \\
\hline LSD 5\%-rel. values & 5.01 & 3.42 & 3.79 & 28.89 \\
\hline
\end{tabular}




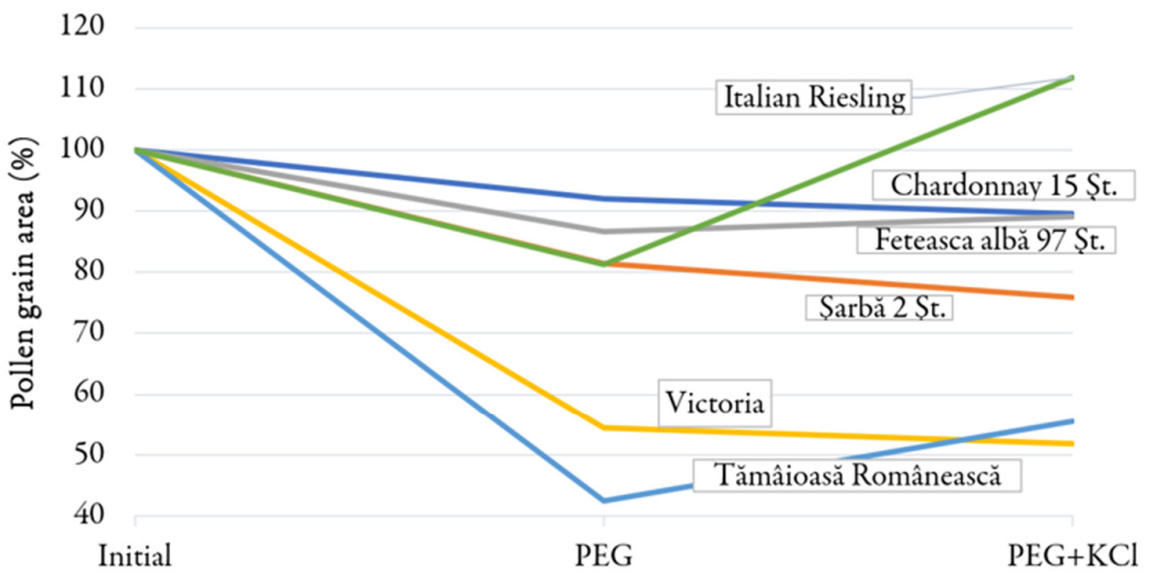

(A)

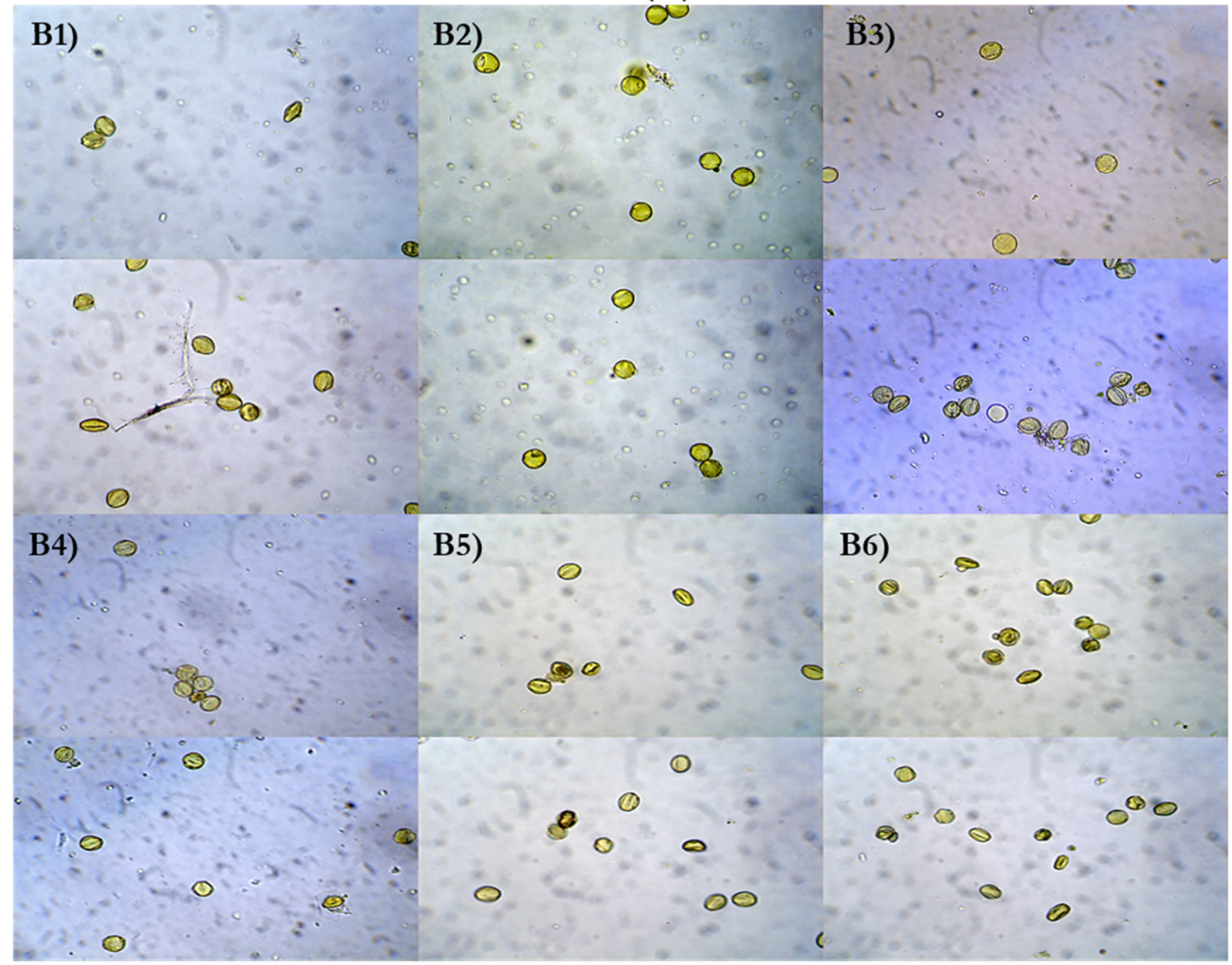

Figure 2. I. (A.) Pollen grain responses to different osmotic stresses applied in some representative grapevine genotypes; (B.) Pollen cytoplasm responses to different osmotic stresses with or without $\mathrm{KCl}$ for three representative grapevine genotypes as contrasting expressions substantiated by intrinsic and induced osmotic adjustment given by image repetitions focused on Olympus microscope at magnification of 20X: B1) 'Italian Riesling' pollen grains exposed to 65\% PEG - cell shape changes because of the decreasing in initial projected cytoplasm; B2) 'Italian Riesling' pollen grains exposed to $65 \% \mathrm{PEG}\left(\mathrm{K}^{+}\right)$- reinitialization and increasing of initial projected cytoplasm in pollen grain cells; B3) 'Chardonnay' 15 Şt. pollen grains exposed to $65 \%$ PEG - partial reinitialization of initial projected cytoplasm in pollen grain cells; B4) 'Chardonnay' 15 Şt. pollen grains exposed to 65\% PEG $\left(\mathrm{K}^{+}\right)$- cell shape changes because of the decreasing in initial projected cytoplasm; B5) 'Tămâioasă Românească’ pollen grains exposed to 55\% PEG - cell shape changes because of the decreasing in initial projected cytoplasm; B6) 'Tămâioasă Românească' pollen grains exposed to 55\% $\operatorname{PEG}\left(\mathrm{K}^{+}\right)$- cell shape changes because of the decreasing in initial projected cytoplasm 


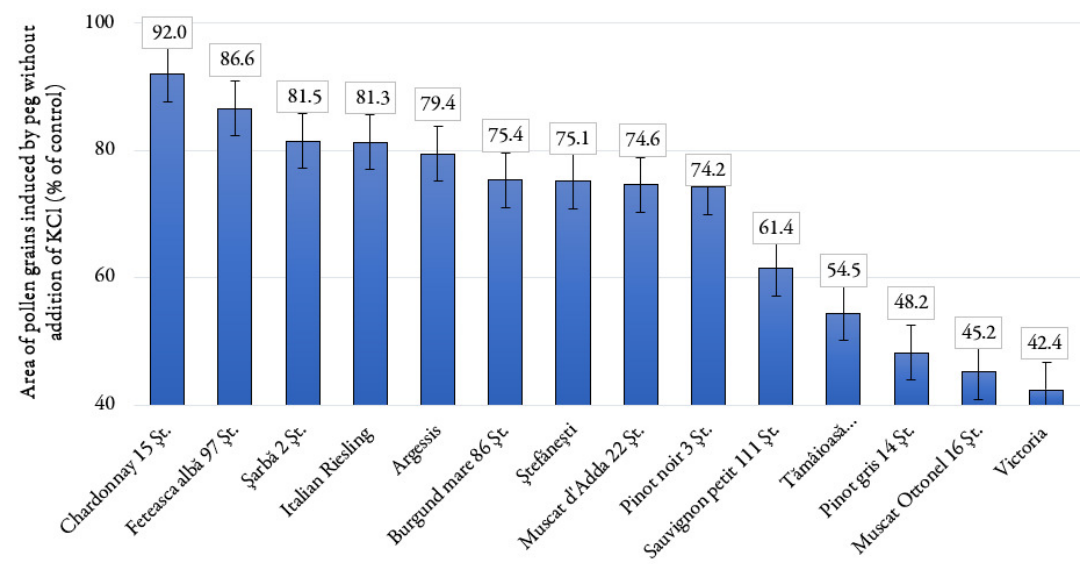

(C)

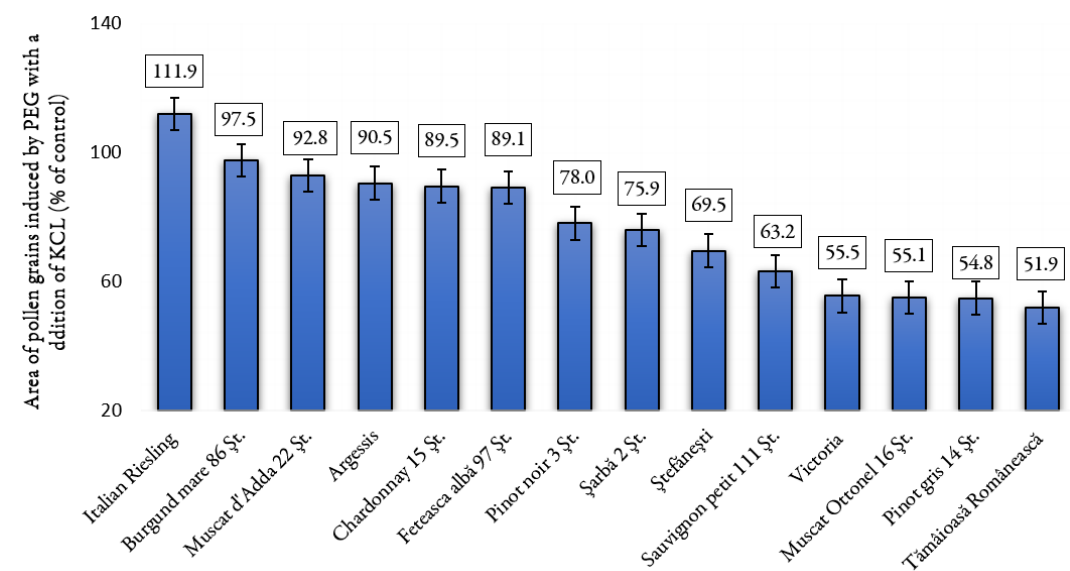

(D)

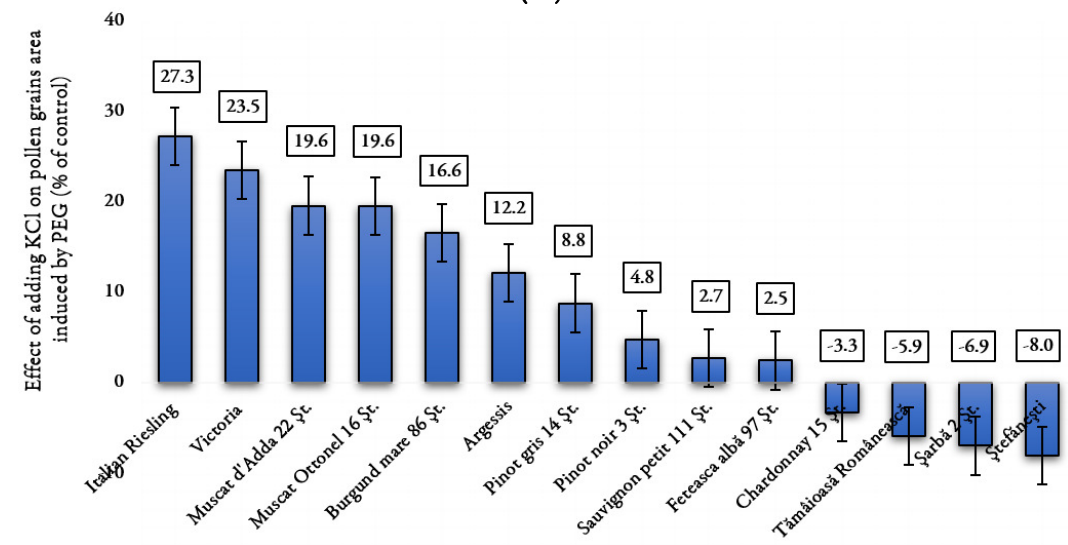

(E)

Figure 2. II. ( $C^{*}$; $D^{*}$; $E^{*}$.) Distribution of means \pm standard deviations $(n=5)$ for projected pollen grains cytoplasm expressed in \% of control, at different levels of osmotic stress. ${ }^{*}$ means that the figure took in consideration effect of PEG solutions with or without addition of $\mathrm{KCl}$ as a mean of two concentrations given by $55 \%$ and $65 \%$ 
Differences between genotypes regarding expressions of osmotic adjustment

Large differences were found in the means of ratio coefficients calculated for expressions of intrinsic, overall and induced osmotic adjustment, among the studied grapevine genotypes (Table 3).

Table 3. ANOVA of ratio coefficients expressed in means which estimate different types of osmotic adjustment expressions induced in pollen grains; $F$ values (bold) were significant for $\mathrm{P}<0.05$; where $\mathrm{DF}$ means degrees of freedom; MS means mean square; Fischer factor means practical $F ; \operatorname{Pr}(>F)$ means theoretical F

\begin{tabular}{|c|c|c|c|c|}
\hline \multicolumn{5}{|c|}{ ANOVA of: } \\
\hline Intrinsic OA expressed in 55\% PEG & DF & MS & Fischer Factor & $\operatorname{Pr}(>F)$ \\
\hline Variables as varieties & 13 & 0.070 & $8.39^{*}$ & 2.09 \\
\hline $\begin{array}{l}\text { Estimation of general errors determined by } \\
\text { all experimental differences }\end{array}$ & 28 & 0.008 & & \\
\hline Intrinsic OA expressed in 65\% PEG & DF & MS & Fischer Factor & $\operatorname{Pr}(>\mathrm{F})$ \\
\hline Variables as varieties & 13 & 0.125 & $11.36^{*}$ & 2.09 \\
\hline $\begin{array}{l}\text { Estimation of general errors determined by } \\
\text { all experimental differences }\end{array}$ & 28 & 0.011 & & \\
\hline Overall OA expressed in 55\% PEG & DF & MS & Fischer Factor & $\operatorname{Pr}(>\mathrm{F})$ \\
\hline Variables as varieties & 13 & 0.130 & $14.14^{*}$ & 2.09 \\
\hline $\begin{array}{l}\text { Estimation of general errors determined by } \\
\text { all experimental differences }\end{array}$ & 28 & 0.009 & & \\
\hline Overall OA expressed in 65\% PEG & $\mathrm{DF}$ & MS & Fischer Factor & $\operatorname{Pr}(>\mathrm{F})$ \\
\hline Variables as varieties & 13 & 0.154 & $16.56^{*}$ & 2.09 \\
\hline $\begin{array}{l}\text { Estimation of general errors determined by } \\
\text { all experimental differences }\end{array}$ & 28 & 0.009 & & \\
\hline Induced OA expressed in 55\% PEG & $\mathrm{DF}$ & MS & Fischer Factor & $\operatorname{Pr}(>\mathrm{F})$ \\
\hline Variables as varieties & 13 & 0.161 & $23.59^{* *}$ & 2.09 \\
\hline $\begin{array}{l}\text { Estimation of general errors determined by } \\
\text { all experimental differences }\end{array}$ & 28 & 0.007 & & \\
\hline Induced OA expressed in 65\% PEG & DF & MS & Fischer Factor & $\operatorname{Pr}(>\mathrm{F})$ \\
\hline Variables as varieties & 13 & 0.099 & $7.40^{*}$ & 2.09 \\
\hline $\begin{array}{l}\text { Estimation of general errors determined by } \\
\text { all experimental differences }\end{array}$ & 28 & 0.013 & & \\
\hline
\end{tabular}

Two close responses for expression of intrinsic osmotic adjustment $(\mathrm{B} / \mathrm{A})$ were found among grapevine genotypes. The limits of variations were from $0.424 \pm 0.019$ in 'Victoria' to $0.885 \pm 0.152$ in 'Fetească albă' 97 Şt. and $0.932 \pm 0.157$ in 'Chardonnay' 15 Şt. (Table 4).

The expression of induced osmotic adjustment (C/B) varied among grapevine genotypes from $0.926 \pm$ 0.075 in 'Ştefăneşti' and $0.939 \pm 0.058$ in 'Şarbă' 2 Şt. to $1.384 \pm 0.138$ in 'Italian Riesling', $1.337 \pm 0.075$ in 'Burgund mare' 86 Şt. and $1.311 \pm 0.072$ in 'Victoria' (Table 4).

The limits of variation for overall osmotic adjustment expression were from $0.527 \pm 0.224$ in 'Tămâioasă Românească' to $1.123 \pm 0.275$ in 'Italian Riesling' (Table 4).

\section{Relationships between expressions of osmotic adjustment in the grapevine varieties set}

The genotype responses to addition of $\mathrm{K}^{+}$to PEG solutions $(\mathrm{C} / \mathrm{B})$ were not correlated with expression of intrinsic $\mathrm{OA}(\mathrm{B} / \mathrm{A})$ (Figure 3). The negative relationship between these two indicators suggested that these two expressions of osmotic adjustment given by means of ratio coefficients (Table 4) analyzed for all fourteen grapevine genotypes represent mechanisms which action independently under drought conditions (Figure 3). 
Table 4. Means \pm standard deviations of ratio coefficients which estimate different types of osmotic adjustment expressions induced in pollen grains; LSD values were corresponded to a significant limit of $5 \%$ and were expressed both, in absolute and relative values

\begin{tabular}{|c|c|c|c|}
\hline Genotype & $\begin{array}{c}\text { Expression of induced } \\
\text { OA }\end{array}$ & $\begin{array}{c}\text { Expression of overall } \\
\text { OA }\end{array}$ & $\begin{array}{c}\text { Expression of intrinsic } \\
\text { OA }\end{array}$ \\
\hline Italian Riesling & $1.384 \pm 0.138$ & $1.123 \pm 0.275$ & $0.818 \pm 0.090$ \\
\hline Burgund mare 86 Şt. & $1.337 \pm 0.075$ & $0.981 \pm 0.254$ & $0.759 \pm 0.073$ \\
\hline Victoria & $1.311 \pm 0.072$ & $0.555 \pm 0.161$ & $0.424 \pm 0.019$ \\
\hline Muscat Ottonel 16 Şt. & $1.269 \pm 0.101$ & $0.551 \pm 0.138$ & $0.452 \pm 0.039$ \\
\hline Muscat d'Adda 22 Şt. & $1.244 \pm 0.023$ & $0.935 \pm 0.259$ & $0.751 \pm 0.057$ \\
\hline Argessis & $1.143 \pm 0.086$ & $0.906 \pm 0.184$ & $0.795 \pm 0.038$ \\
\hline Pinot gris 14 Şt. & $1.113 \pm 0.091$ & $0.560 \pm 0.266$ & $0.492 \pm 0.090$ \\
\hline Pinot noir 3 Şt. & $1.053 \pm 0.110$ & $0.782 \pm 0.233$ & $0.743 \pm 0.038$ \\
\hline Feteasca albă 97 Şt. & $1.031 \pm 0.100$ & $0.903 \pm 0.291$ & $0.885 \pm 0.152$ \\
\hline Sauvignon petit 111 Şt. & $1.031 \pm 0.038$ & $0.633 \pm 0.144$ & $0.615 \pm 0.035$ \\
\hline Chardonnay 15 Şt. & $0.978 \pm 0.055$ & $0.908 \pm 0.343$ & $0.932 \pm 0.157$ \\
\hline Tămâioasă Românească & $0.953 \pm 0.060$ & $0.527 \pm 0.224$ & $0.557 \pm 0.092$ \\
\hline Şarbă 2 Şt. & $0.939 \pm 0.058$ & $0.759 \pm 0.138$ & $0.816 \pm 0.051$ \\
\hline Ştefăneşti & $0.926 \pm 0.075$ & $0.696 \pm 0.254$ & $0.752 \pm 0.033$ \\
\hline Average & 1.122 & 0.773 & 0.699 \\
\hline LSD 5\%-absolute values & 0.05 & 0.07 & 0.07 \\
\hline LSD 5\%-relative values & 4.5 & 9.1 & 10.0 \\
\hline
\end{tabular}

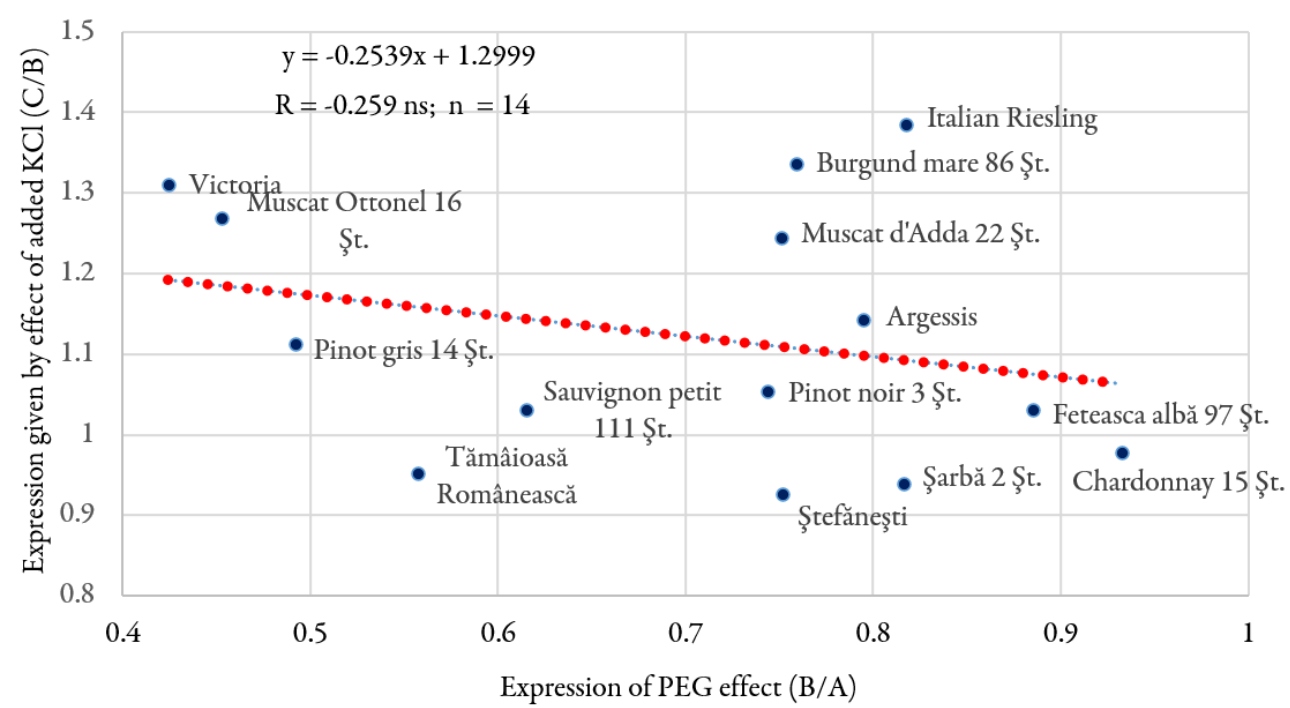

Figure 3. Relationship between effect of PEG (intrinsic OA expression) and addition of $\mathrm{KCl}$ (induced OA expression)

Blue line shows the global linear regression for all fourteen genotypes $(\mathrm{R}=(-) 0.259$ (IS); $\mathrm{P}<0.05)$

The positive relationship established between ratios $\mathrm{C} / \mathrm{A}$ and $\mathrm{B} / \mathrm{A}$ was significant $\left(\mathrm{R}=0.821^{* *}\right)$ (Figure 4). The expression of overall osmotic adjustment $(\mathrm{C} / \mathrm{A})$ integrated that of intrinsic osmotic adjustment $(\mathrm{B} / \mathrm{A})$, explained by $50 \%$ of its variation (Figure 4 ). 


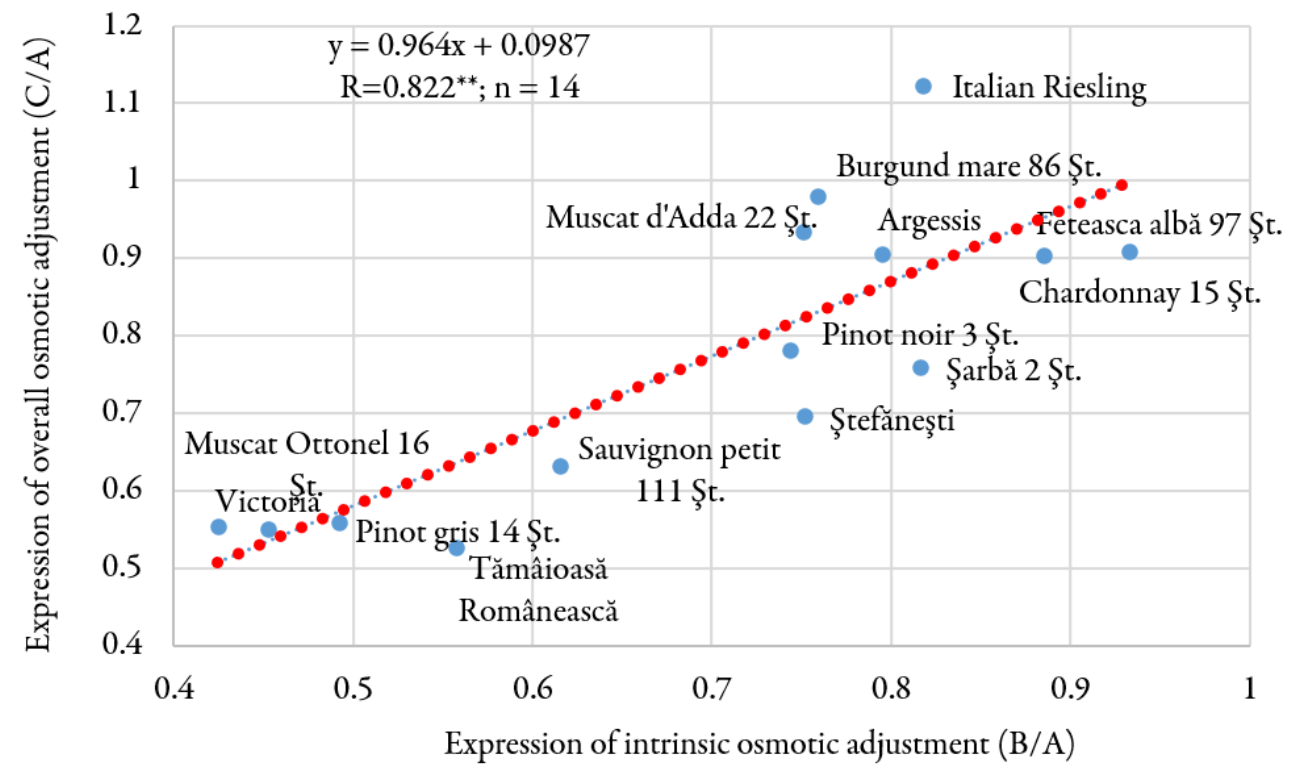

Figure 4. Relationship between intrinsic and overall OA expressions

Blue line shows the global linear regression for all fourteen genotypes $\left(\mathrm{R}=(+) 0.822^{* *} ; \mathrm{P}<0.05\right)$

The positive relationship between overall and induced osmotic adjustment was not established (Figure 5), but several varieties such as 'Italian Riesling', 'Burgund mare' 86 Şt. and 'Muscat d'Adda' 22 Şt. had high mean values of ratio coefficients for both indicators (Figure 5).

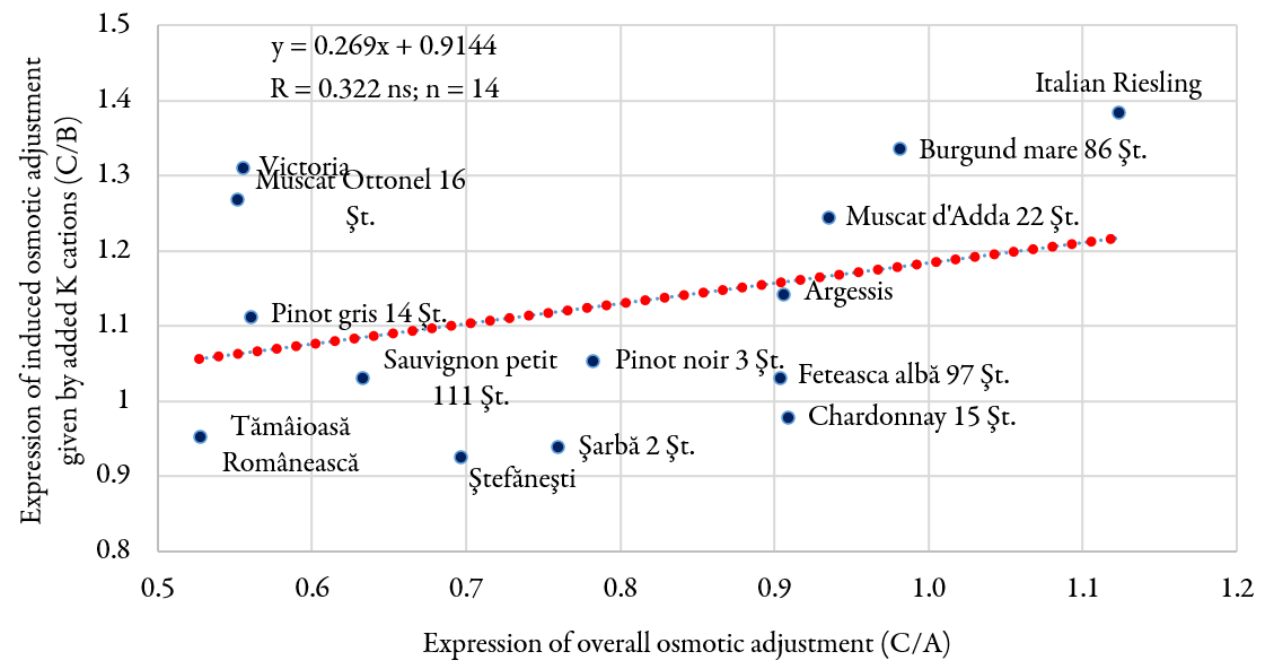

Figure 5. Relation between overall and induced OA expressions

Blue line shows the global linear regression for all fourteen genotypes $(\mathrm{R}=(+) 0.322(\mathrm{IS}) ; \mathrm{P}<0.05)$.

The overall analysis of correlations for all fourteen genotypes underlined several genotypes which are above regression line such as 'Italian Riesling', 'Burgund mare' 86 Şt., 'Muscat d'Adda' 22 Şt., 'Muscat Ottonel' 16 Şt. and 'Victoria', but 'Muscat d'Adda' 22 Şt. was closely kept in the linearity of the overall analysis interval (Figure 3; Figure 4; Figure 5). 


\section{Discussion}

Responses differently expressed for intrinsic and induced osmotic adjustment in pollen grains suggested that grapevine genotypes might use different mechanisms that are activated at the time of water stress with different levels of solute accumulation. Rogiers et al. (2017) have been found that in grape varieties, aquaporins reperesent an important mechanism which control water flow through tissues and cells, but there are still important uncertainties that need to be resolved concerning those key processes that drive water accumulation in the cell. It has been suggested that the rapid increase in solute accumulation within the ripening grape berry mesocarp, including sugars, organic acids, $\mathrm{K}^{+}$and other cations such as $\mathrm{Mg}^{2+}$ drives osmotic water influx (Mpelasoka et al., 2008; Rogiers et al., 2017). After the cell turgescence is established, the cell extends wall and drives growth (Serpe and Matthew, 2000; Rogiers et al., 2017).

\section{Expression of intrinsic $O A$}

The reason why two close responses were found for expression of intrinsic OA is because grapevine is generally a "drought-avoiding" specie (Chaves et al., 1987; Schultz, 2003; Chaves et al., 2010). Chaves et al. (2010) have been characterized the grapevine genotypes as "isohydric" (drought avoiders or "pessimistic") and "anisohydric" with an "optimistic" response, which show a lower control over stomatal aperture under water stress (Schultz, 2003; Soar et al., 2006; Chaves et al., 2010). Studies modulated for 'Chardonnay's drought sensitivity characterized this variety as "anisohydric". At the physiological level, stomata closure is one of the first response to water stress, in order to prevent the hydraulic failure (Charrier et al., 2018; Cardone et al., 2019). Intrinsic OA closely expressed by the mean values of $0.932 \pm 0.157$ in 'Chardonnay' 15 Şt., $0.885 \pm$ 0.152 in 'Fetească albă' 97 Şt., $0.818 \pm 0.090$ in 'Italian Riesling' and $0.816 \pm 0.051$ in 'Şarbă' 2 Şt. could indicate mechanisms involved in the ABA biosynthetic pathway (Chaves et al., 2010), that are activated under drought conditions (Rossdeutsch et al., 2016). Rossdeutsch et al. (2016) have been stated that an absolute relationship between high $\mathrm{ABA}$ production capacity and known drought tolerance in the field was not established, supporting that drought tolerance could be expressed through different mechanisms (Serra et al., 2014).

\section{Expression of induced $O A$}

Addition of $\mathrm{KCl}$ to $\mathrm{PEG}$ solutions to which pollen grains were exposed, produced a change in the shape and size, either by restoring the initial size, or even increasing or reducing the pollen grain cytoplasm (David, 2012). 'Italian Riesling' increased pollen grains cytoplasm more than the other genotypes in PEG solutions with added $\mathrm{KCl}$ and had values $>1$ for both expressions of induced and overall $\mathrm{OA}$. The results underlined the high $\mathrm{K}^{+}$accumulation capacity of 'Italian Riesling' as Bora et al. (2016) have been found it in their study.

Rogiers et al. (2017) have been stated that the pollen expressions of osmotic adjustment in grapevines genotypes occurred as a result of $\mathrm{VvK} 1.2$ gene effect (inward rectifying shaker-like $\mathrm{K}^{+}$channel), on potassium transport, expressed in berry flesh, phloem tissues and perivascular cells of the vascular bundles. This gene is located on the chromosome 4 in the grapevine genome and it is expressed specifically than other genes involved in the osmotic adjustment expressions. Drought stress induced a two-to threefold increase in the VvK1.2 gene expression at post veraison, further substantiating that $\mathrm{K}^{+}$transport into berries is affected by drought stress (Cuéllar et al., 2013). $\mathrm{K}^{+}$as an osmolyte, maintains pollen hydration and pollen tube growth to the ovary (Fan et al., 2001; Rehman et al., 2004). Therefore, the success of pollination and fertilization of the ovule, influenced by the capacity of $\mathrm{K}^{+}$accumulation in the cells, in all phenological stages (Rogiers et al., 2017), determine the grape yield and quality.

K cation is very important for all stages of berry development (Hale, 1977; Hrazdina et al., 1984; Rogiers et al., 2006a; Martins et al., 2012; Rogiers et al., 2017). In the berry cells, $\mathrm{K}^{+}$is one of the varieties dependent and linked to ripening disorders late in ripening (Tilbrook and Tyerman, 2008; Fuentes et al., 2010; Rogiers et al., 2017) 
Our study initiated to characterize the expressions of OA in the grapevine set found induced OA with implication of $\mathrm{K}^{+}$expressed differently in the pollen grains. Rogiers et al. (2017) have been explained the mechanisms in which $\mathrm{K}^{+}$could action differently in some grapevine genotypes at the cellular and sub-cellular levels. The lack of accumulation of $\mathrm{K}$ cations in the cell cytoplasm is generally influenced by backflow, phloem unloading, long distance phloem transport and retrieval phenomena. At the other hand, grapevine is a perennial plant which develops different adaptation pathways for each phenological stage under drought conditions. These might be a cause why some grapevine genotypes successfully accumulated $\mathrm{K}$ cations in all phenological stages than others and this difference in the capacity of $\mathrm{K}^{+}$accumulation could be used in the screening of grapevine tolerance.

\section{Conclusions}

The study found differences both in the measurements of projected cytoplasm area and expressions of osmotic adjustment in the grapevine pollen grains. Therefore, pollen grain test proposed by Morgan (1999) in wheat could be used as a quick screening method for establishing the level of drought sensitivity in grape plants.

The analysis initiated to characterize the expressions of OA in the grapevine set found induced OA with implication of $\mathrm{K}^{+}$expressed differently in the pollen grains. Because, the capacity of $\mathrm{K}^{+}$accumulation at cellular and sub-cellular levels is expressed in all phenological stages developed by grapevine and determine the yield and quality of grapes under drought conditions, drought sensitivity could be quantified through estimation of induced osmotic adjustment given by $\mathrm{K}^{+}$. Induced osmotic adjustment given by $\mathrm{K}^{+}$was expressed with the highest values in the pollen grains of several genotypes such as 'Italian Riesling', 'Burgund mare' 86 Şt., 'Muscat d'Adda' 22 Şt., 'Muscat Ottonel' 16 Şt., 'Pinot gris' 14 Şt. and 'Argessis' and with the lowest value in 'Tămâioasă Românească.

Further research will be address to the induced osmotic adjustment expressed by $\mathrm{K}$ cations tested on a larger grapevine germplasm. These data in correlation with molecular information regarding VvK1.2 gene expression will be important for a complete drought tolerance characterization of the grapevine genotypes.

\section{Authors Contributions}

Conceptualization: MD; Data curation: DEV, IDT, AT, C-MC, MFB; Formal analysis: MD and AT;

Investigation: $\mathrm{MD}$ and AT; Methodology: MD; Resources Software: National Research and Development Institute for Biotechnology in Horticulture Ştefăneşti-Argeş; Writing-original draft: MD; Writing-review and editing: AT

All authors read and approved the final manuscript.

\section{Acknowledgements}

This research received no specific grant from any funding agency in the public, commercial, or not-forprofit sectors. We acknowledge the Virology and Breeding Laboratories from National Research and Development Institute for Biotechnology in Horticulture Ştefăneşti-Argeş, for their technical assistance.

\section{Conflict of Interests}

The authors declare that there are no conflicts of interest related to this article. 


\section{References}

Bănică C, Petcu E, Giura A, Săulescu NN (2008). Relationship between genetic differences in the capacity of osmotic adjustment and other physiological measures of drought resistance in winter wheat (Triticum aestivum L.). Romanian Agricultural Research 25:7-11. https://www.researchgate.net/publication/268179519

Blum A (2009). Effective use of water (EUW) and not water-use-efficiency (WUE) is the target of crop yield improvement under drought stress. Field Crop Research 112:119-123. https://doi.org/10.1016/j.fcr.2009.03.009

Bora FD, Donici A, Oşlobeanu A, Fițiu A, Babeş IC (2016). Qualitative assessment of the white wine varieties grown in Dealu Bujorului Vineyard, Romania. Notulae Botanicae Horti Agrobotanici 44(2):593-602. https://doi.org/10.15835/nbha44210434

Cardone MF, Perniola R, Catacchio CR, Alagna F, Rotunno S, Crupi P, ... Bergamini C (2019). Grapevine adaptation to drought: New candidate genes for genotype-dependent response. BIO Web of Conferences 15, 01016, 42 ${ }^{\text {nd }}$ World Congress of Vine and Wine. https://doi.org/10.1051/bioconf/20191501016

Charrier G, Delzon S, Donnec JC, Zhang L, Delmas CEL, Merlin I, ... Gambetta GA (2018). Drought will not leave your glass empty: Low risk of hydraulic failure revealed by long-term drought observations in worlds top wine regions. Science Advances 4. https://doi.org/10.1126/sciadv.aao6969

Chaves MM, Tenhunen JD, Harley P, Lange OL (1987). Gas exchange studies in two Portuguese grapevine cultivars. Physiologia Plantarum 70:639-647. https://doi.org/10.1111/j.1399-3054.1987.tb04318.X

Chaves MM, Santos TP, Souza CR (2007). Deficit irrigation in grapevine improves water-use-efficiency while controlling vigour and production quality. Annals of Applied Biology 150:237-252. https://doi.org/10.1111/j.17447348.2006.00123.x

Chaves MM, Zarrouk O, Francisco R, Costa JM, Santos T, Regalado AP, ... Lopes CM (2010). Grapevine under deficit irrigation: hints from physiological and molecular data. Annals of Botany 105:661-676. https://doi.org/10.1093/aob/mcq030

Cuéllar T, Azeem F, Andrianteranagna M, Pascaud F, Verdeil JL, Sentenac H (2013). Potassium transport in developing fleshy fruits: the grapevine inward $\mathrm{K}^{+}$channel VvK1.2 is activated by CIPK-CBL complexes and induced in ripening berry flesh cells. The Plant Journal 73:1006-1018. https://doi.org/10.1111/tpj.12092

David M (2009). Osmotic adjustment capacity and cuticular transpiration in several wheat cultivars cultivated in Algeria. Romanian Agricultural Research 26:29-33. https://www.researchgate.net/publication/266399528

David M (2012). Pollen grain expression of intrinsic and osmolyte induced osmotic adjustment in a set of wheat cultivars. Romanian Agricultural Research 29:45-52. https://www.researchgate.net/publication/266401970

Fan LM, Wang YF, Hong W, Wu WH (2001). In vitro Arabidopsis pollen germination and characterization of the inward potassium currents in Arabidopsis pollen grain protoplasts. Journal of Experimental Botany 52:1603-1614. https://doi.org/10.1093/jexbot/52.361.1603

Fuentes S, Sullivan W, Tilbrook J, Tyerman SD (2010). A novel analysis of grapevine berry tissue demonstrates a varietydependent correlation between tissue vitality and shrivel. Australian journal of Grape Wine Research 13:66-71. https://doi.org/10.1111/j.1755-0238.2010.00095.x

Glăman G, Dejeu L, Brânduşe E, Şerdinescu A, Ion M (2018). Soiuri noi de viță-de-vie şi portaltoi creaţi în România [New grapevine cultivars and rootstock genotypes obtained in Romania]. In: Glăman G, Dejeu L, Brânduşe E, Şerdinescu A, Ion M (Eds). Ampelografia României [Romanian Ampelography] IX. Ceres Bucureşti [Bucharest] pp. 63-64, 81-83, 185-186, 215-217, 395, 396, 397, 407, 408.

Hale CR (1977). Relation between potassium and the malate and tartare contents in grape berries. Vitis: Journal of Grapevine Research 16:9-19. https://doi.org/10.5073/vitis.1977.16.9-19

Hrazdina G, Parsons GF, Mattick LR (1984). Physiological and biochemical events during development and ripening of grape berries. American Journal of Enology and Viticulture 35:220-227. https://www.ajevonline.org/content/35/4/220

Kikuta SB, Richter H (1988). Rapid osmotic adjustment in detached wheat leaves. Annals of Botany 63(2):167-172. https://doi.org/10.1093/oxfordjournals.aob.a087647

Martins V, Cunha A, Gerós H, Hanana M, Blumwald E (2012). Mineral compounds in grape berry. In Gerós H, Chaves MM, Delrot S (Eds.). The biochemistry of the grape berry. Sharjah: Bentham Science pp. 23-43. https://doi.org/10.2174/97816080536051120101

Morgan JM (1980). Osmotic adjustment in the spikelets and leaves of wheat. Journal of Experimental Botany 31:655665. https://doi.org/10.1093/jxb/31.2.655 
Morgan JM (1983). Osmoregulation as a selection criterion for drought tolerance in wheat. Australian Journal of Agricultural Research 34:607-614. https://doi.org/10.1071/AR9830607

Morgan JM, Hare RA, Fletcher RJ (1986). Genetic variation in osmoregulation in bread and durum wheats and its relationship to grain yield in a range of field environments. Australian Journal of Agricultural Research 37:449457. https://doi.org/10.1071/AR9860449

Morgan JM (1999). Pollen grain expression of a gene controlling differences in osmoregulation in wheat leaves: a simple breeding method. Australian Journal of Agricultural Research 50:953-962. https://doi.org/10.1071/AR98143

Mpelasoka BS, Schachtman DP, Treeby MT, Thomas MR (2008). A review of potassium nutrition in grapevines with special emphasis on berry accumulation. Australian Journal of Grape Wine Research 9:154-168. https://doi.org/10.1111/j.1755-0238.2003.tb00265.x

Moud AAM, Yamagishi T (2005). Application of project pollen area response to drought stress to determine osmoregulation capability of different wheat (Triticum aestivum L.) cultivars. International Journal of Agriculture and Biology 7(4):604-605.

Mouline K, Véry AA, Gaymard F, Boucheren J, Pilot G, Devic M, ... Sentenac H (2002). Pollen tube development and competitive ability are impaired by disruption of a Shaker $\mathrm{K}^{+}$channel in Arabidopsis. Genes\&Development 16:339-350. https://doi.org/10.1101/gad.213902

Oprea A, Indreaş A (2000). Floarea şi polenul [The flower and pollen]. In: Oprea A, Indreaş A (Eds). Viticultura [Viticulture]. Ceres Bucureşti [Bucharest] pp.63-64.

Parker WC, Pallardy SG (1985). Genotypic variation in tissue water relations of leaves and roots of black walnut (Juglans nigra) seedlings. Physiologia Plantarum 64:105-110. https://doi.org/10.1111/j.1399-3054.1985.tb01219.x

Patil BS, Ravikumar RL (2011). Osmotic adjustment in pollen grains: a measure of drought adaptation in sorghum? Current Science 100(3):377-382. https://www.researchgate.net/publication/257299541

Rehman S, Rha ES, Ashraf M, Lee KJ, Yun SJ, Kwak YG (2004). Does barley (Hordeum vulgare L.) pollen swell in fractions of a second? Plant Science 167:137-142. https://doi.org/10.1016/j.plantsci.2004.03.013

Rodrigues ML, Chaves MM, Wendler R, David MM, Quick WP, Leegood RC, ... Pereira JS (1993). Osmotic adjustment in water stressed grapevine leaves in relation to carbon assimilation. Australian Journal of Plant Physiology 20:309321. https://doi.org/10.1071/PP9930309

Rogiers YS, Greer DH, Hatfield JM, Orchard BA, Keller M (2006a). Mineral sinks within ripening grape berries Vitis vinifera (L.). Vitis-Geilweilerhof 45(3):115-123. https://www.researchgate.net/publication/282500219

Rogiers YS, Zelmari AC, Walker RR, Deloire A, Tyerman SD (2017). Potassium in the grape (Vitis vinifera L.) berry: transport and function. Plant Science 8:1629. https://doi.org/10.3389/fpls.2017.01629

Rossdeutsch L, Edwards E, Cookson SJ, Barrieu F, Gambetta GA, Delrot S, Ollat N (2016). ABA-mediated responses to water deficit separate grapevine genotypes by their genetic background. BMC Plant Biology 16:91. https://doi.org/10.1186/s12870-016-0778-4

Schultz HR (2003). Differences in hydraulic architecture account for near-isohydric and anisohydric behavior in two field-grown Vitis vinifera L. cultivars during drought. Plant Cell and Environment 26:1393-1405. https://doi.org/10.1046/j.1365-3040.2003.01064.x

Serpe M, Matthews M (2000). Turgor and cell wall yielding in dicot leaf growth in response to changes in relative humidity. Australian Journal of Plant Physiology 27:142-147. https://doi.org/10.1071/PP00055

Serra I, Strever A, Myburgh PA, Deloire A (2014). Review: the interaction between rootstocks and cultivars (Vitis vinifera L.) to enhance drought tolerance in grapevine. Australian Journal of Grape and Wine Research 20:1-14. https://doi.org/10.1111/ajgw.12054

Soar CJ, Speirs J, Maffei SM, Penrose AB, McCarthy MG, Loveys BR (2006). Grape vine varieties Shiraz and Grenache differ in their stomatal response to VPD: apparent links with ABA physiology and gene expression in leaf tissue. Australian Journal of Grape and Wine Research 12:2-12. https://doi.org/10.1111/j.1755-0238.2006.tb00038.X

Sobrado MA (1986). Aspects of tissue water relations and seasonal changes of leaf water potential components of evergreen and deciduous species coexisting in tropical dry forest. Oecologia 68:413-416. https://doi.org/10.1007/BF01036748

Sobrado MA (1990). Drought response of tropical corn. 2. Leaf expansion rate and water relations under controlled conditions. Maydica 35:227-234. https://www.cabdirect.org/cabdirect/abstract/19901617342

Steel RG, Torrie JH, Dickey DA (1997). Principles and procedures of statistics: a biometrical approach, 3rd. WCB MCgraw-Hill, Boston. 
Tillbrook J, Tyerman SD (2008). Cell death in grape berries varietal differences linked to xylem pressure and berry weight loss. Functional Plant Biology 35:173-184. https://doi.org/10.1071/FP07278

Tschaplinski TJ, Blake TJ (1989). Water-stress tolerance and late-season organic solute accumulation in hybrid poplar. Canadian Journal of Botany 67(6):1681-1688. https://doi.org/10.1139/b89-212

Turner NC, Jones MM (1980). Turgor maintenance by osmotic adjustment: a review and evaluation. In: Turner NC, Kramer PJ (Eds). Adaptation of plants to water and high temperature stress. John Wiley \& Sons London pp 87 103.

Zhao LN, Shen LK, Zhang WZ, Zhang W, Wang Y, Wu WH (2013). $\mathrm{Ca}^{2+}$-dependent protein kinase 11 and 24 modulate the activity of the inward rectifying $\mathrm{K}^{+}$Channels in Arabidopsis pollen tubes. The Plant Cell 25:649-661. https://doi.org/10.1105/tpc.112.103184
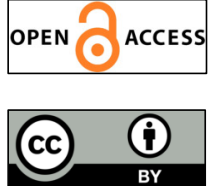

The journal offers free, immediate, and unrestricted access to peer-reviewed research and scholarly work. Users are allowed to read, download, copy, distribute, print, search, or link to the full texts of the articles, or use them for any other lawful purpose, without asking prior permission from the publisher or the author.

License - Articles published in Notulae Scientia Biologicae are Open-Access, distributed under the terms and conditions of the Creative Commons Attribution (CC BY 4.0) License.

(c) Articles by the authors; SHST, Cluj-Napoca, Romania. The journal allows the author(s) to hold the copyright/to retain publishing rights without restriction. 